\title{
APOLLO AND HIS PURPOSE IN SOPHOCLES' OEDIPUS TYRANNUS
}

\author{
Stuart Lawrence
}

\begin{abstract}
Apollo actively intervenes in the fulfilment of Oedipus' destiny through oracles and immanently in the onstage action. Rather than to punish him for any offence, the god's purpose appears to be to impress upon Oedipus his existential insignificance. In the context of an ordered but absurd universe, Sophocles emphasises the paradox of the moral greatness of a man whose 'official' existential value is less than zero.
\end{abstract}

With the partial exception of Athena in the Ajax, Sophocles' gods are largely inscrutable. In no play is this inscrutability more problematical than in the Tyrannus, and the resulting difficulties for the interpreter are well stated by R. Parker (1999), who warns us about drawing inferences where the poet is silent.

\begin{abstract}
Sensitive critics have always been struck by these silences of Sophocles' text, of which the most famous is doubtless the apparent silence in Oedipus Tyrannus about the ultimate motivation for the destiny prophesied for Laius and Oedipus. In a sense the central problem for any study of Sophocles' presentation of the divine is that of responding to these silences: at all events, it is at this point that the paths of even the best critics diverge. Does Sophocles leave the divine will unexplained because to reason about it would be a distraction from the true human centre of the plays? Or is the point rather the ultimate incomprehensibility to mortals of the divine world? And if so, if the ways of the gods are incomprehensible, is that because those ways are good, but human comprehension weak? Or because mortals seek justice where none is to be found? ${ }^{1}$
\end{abstract}

Apollo never appears in person in the Tyrannus, though he declares his condition for the salvation of Thebes in the oracle that requires the discovery of Laius' killer while he predicts the parricide in the original oracle to Laius and both the parricide and the incest in the later oracle given to Oedipus. More controversy surrounds whether Apollo (A) merely declares Oedipus' destiny² or (B) positively activates it through the circumstances of the various oracles and perhaps also by intervening further during the course of the onstage action. Then there is the question of the god's overall purpose. Does he actively will the destiny he predicts? - which would seem more likely in the case of (B), though not excluded on either scenario. Further, if Apollo wills and approves of Oedipus' destiny, is he motivated by a hostile desire to punish him, as Athena punishes Ajax - and, if so, for what actual or foreseen ${ }^{3}$ offence? - or out of

\footnotetext{
${ }^{1}$ Parker 1999: 26. Hutchinson (1999: 63) warns us that '[p]art of the impact of the OT lies in its incommensurability and uncanniness; in consequence, criticism has to be unusually cautious in spelling out what the play suggests.'

2 E.g. Dodds 1966: 42; Kirkwood 1958: 276; Gellie 1972: 105.

${ }^{3}$ As Artemis' demand for the sacrifice of Iphigenia might perhaps be regarded as a punishment for crimes she foresees that the Aeschylean Agamemnon will commit at Troy (Aes. Ag. 104-59). Although it may seem bizarre to speak of punishing an offence yet to be committed, there is perhaps no moral objection if
} 
a general and more impersonal desire to deflate the pretensions of a mortal, a corollary perhaps of his traditional concern with human self-knowledge? Is Oedipus then innocent of actual wrongdoing, like Euripides' Heracles? In which case the god (and indeed the universe) might seem unjust, as is the case with Hera and the world of Euripides' Heracles. ${ }^{4}$ On the other hand, if the play fails to engage the audience's sense of injustice, that may be because the focus is less on the morality of the divinely imposed destiny than on that of the hero's efforts to cope with it.

Before we turn to examining these issues something should be said about the use of the term 'destiny' here. I take it to mean 'that which has been appointed or pre-ordained', whether, in this play, by Apollo or by some unnamed impersonal power. Destiny does not imply determinism in the strict philosophical sense. ${ }^{5}$ Rather, certain key events can be seen as pre-ordained but there is no question of an unbroken causal chain. According to Zeus, the Homeric Odysseus is destined to return home (and the god issues instructions to Hermes accordingly - which implies that he approves of this destiny whether or not he appointed it himself) (Od. 5.28-42), but that does not mean that all the hero's thoughts and actions on the way home are predetermined to the last detail. It is at least 'appointed' that Oedipus kill his father (though not necessarily deliberately); and it may also perhaps even be appointed that he meet him where he does (since the 'coincidence' is extraordinary), but not obviously destined that he kill his father's attendants. Moreover, there is a strong sense that Oedipus acts as an independent agent at the crossroads, without intimation of divine participation through mental invasion. Similarly, Apollo's foreknowledge should not be equated with omniscience, but should be seen as confined to particular events in which he takes an interest. The traditional Greek gods are, after all, thoroughly anthropomorphic and have not attained the sophistication of theological or philosophical abstractions. In any case, the gap between fatalism and a more rigid determinism is a major reason for the 'silences' to which Parker refers. The problem is to know what can be appropriately inferred from what Sophocles actually tells us; and there are no strict rules regulating what inferences can be drawn when we are dealing with a fictional world. We are limited by the expectations of the genre and by subtle (and sometimes not so subtle) suggestions on the part of the author. ${ }^{6}$

It is time then to address the first of our main questions, that is to consider if Apollo actively participates in events or whether it is right to assert that

the offence can be regarded as voluntary. But this is admittedly problematical in a world in which events can be overdetermined (i.e. simultaneously determined by god and mortal). However, for a different view of Artemis, see Lawrence 1976.

${ }^{4}$ For a discussion of this issue, see Lawrence 1998.

${ }^{5}$ See Dodds 1966: 42, Lurje 2004: 244-5.

${ }^{6}$ One thinks of the way in which Homer virtually asks us to ignore the notion that Orestes' mother's death was brought about by matricide $(\mathrm{Od}$. 3.306-10). Orestes ordered a grave for his mother, but Homer is silent about her death itself. 
There is not one supernatural event in it [the play], no gods...nothing that is not, given the mythical situation, inexorably logical and human. So far as the action is concerned, it is the most relentlessly secular of the Sophoclean tragedies. Destiny, fate and the will of the gods do indeed loom ominously behind the human action, but that action, far from suggesting primeval rituals and satanic divinities, reflects, at every point, contemporary realities familiar to the audience that first saw the play. ${ }^{7}$

Let us examine the causation, focussing on both the divine and the human factors and on their interplay. This will be important in deciding the degree of Oedipus' personal responsibility. We begin with the two earlier oracles that precede the onstage action.

(1) Laius' destiny was to die at the hands of whatever son might be born (hostis genoit') of him and Jocasta. ${ }^{8}$ Thus expressed, this oracle seems to be conditional on the birth of a child and to leave open the possibility that no child would be born. In that case Oedipus' destiny would be contingent upon the actions of Laius. But of course Laius postponed his 'evasive action' until it was too late and Oedipus' subsequent destiny depended in part on his father's attempt to expose him.

(2) Oedipus was alerted by an allegation that the king and queen of Corinth were not his true parents (779-80). Now, logically, without this (or some such) event Oedipus' destiny could not have occurred, and again logically, Apollo either inspired or merely foresaw it. But how logical are we allowed to be? If we think in terms of a primitive fatalism rather than philosophical determinism, perhaps not very logical at all. The question is further complicated or indeed muddied by dramaturgical considerations. Do we have to allow the event as a simple plot contrivance? Moreover, this is a much broader problem that besets the whole issue of apparent coincidences in the play, so that, in the final analysis, we have to be prepared to admit the possibility of the illogical. But that way madness lies, and, if we took that path, we would find ourselves unable to conduct an argument or offer an interpretation. So let us simply honestly register that possibility and move on. At any rate, Oedipus was inspired by the drunken allegation to ask the oracle for the identity of his parents, but the god denied him an answer, sending him away 'dishonoured' (atimon, 789) and bluntly stating that he would kill his father and marry his mother. ${ }^{9}$ Oedipus then seemingly forgot that his question remained unanswered and assumed that the king and queen of Corinth were indeed his true parents. Accordingly, he decided to avoid Corinth and in doing so he set out on the road to Thebes, bumped into and killed his real father.

In sum, Apollo's oracular declaration in the circumstances entails effective intervention; the oracles act as contributing causes of the destiny they predict, through the reactions of those who receive them. But since these human reactions are (we presume) infallibly foreseen by a god, and thus can be safely factored into a broader divine purpose (if such exists), the gap between merely predicting and fully

\footnotetext{
${ }^{7}$ Knox 1984: 134. See also Rehm 1992: 109.

${ }^{8}$ For the translation of hostis genoit' see Jebb ad loc.

${ }^{9}$ Oedipus was touchy about his status: for which see Gregory 1995: 143.
} 
determining narrows considerably. ${ }^{10}$ In other circumstances declaration does not entail effective intervention. The prophecy that Athena's anger at Ajax will not outlast the day (Aj. 737-57) influences the behaviour of the hero's philoi who hurry to save him by preventing him from leaving his tent; but, because it is already too late, the information does not affect the outcome. The oracles in the Trachiniae are known in advance but neither properly understood nor such as to inspire or facilitate any specific attempt to avoid them. For how does one avoid dying or finding peace, or dying at the hands of a dead being (Trach. 1159-73)? Parricide, on the other hand, is an act that one might easily attempt to avoid.

The actual events at the crossroads are explicable in fully human terms. There is no sense of divine involvement after the situation has been set up by the oracle and by 'coincidence'. The focus now is Oedipus' character and its contribution to the parricide. We shall return to this presently when considering whether the god punishes him for a specific offence.

Confronted with the plague, Oedipus is required to find a solution, and it comes from the god in the form of a puzzle. Oedipus is to find the killers of Laius (100-1, tous autoentas, 107). Apollo thus provides essential information (that the pollution is caused by Laius' murder) but also misleads (in suggesting that there was more than one killer), ${ }^{11}$ a deception which is reinforced by the sole surviving witness's lie that Laius was killed by robbers. To confuse matters further, presently there will be a reference to a story that he was killed by 'travellers' (292). These confusions serve an obvious dramatic function, so that again we have to wonder whether the god's reference to a plurality of killers is more significantly dramaturgical than theological. ${ }^{12} \mathrm{In}$ any case, Oedipus now has sufficient information to begin an investigation, which he does in a spirit of determination and pious cooperation with the god while ironically cursing himself and thus perhaps aggravating his fate (cf. 1381-3). Instead of further interrogating the witness (who can also tell them that the slaughter occurred at a triple crossroads), Oedipus infers (from 378) the existence of a conspiracy hatched in Thebes, and no further useful information emerges until Jocasta happens to refer to the crossroads (716), in the course of an attempt to disprove prophecy and not in response to Oedipus' investigation. (Again we can see this as the work of the god or as purely dramaturgical.) At this point Oedipus wonders if he himself may be the murderer, and so he sends for the survivor (765). However, there is no reason to think that the truth would have emerged from a further investigation without the contribution of the Corinthian shepherd, ${ }^{13}$ and his arrival is clearly the work of Apollo. ${ }^{14}$

\footnotetext{
${ }^{10}$ A seer might have declared Oedipus' destiny to him, but he could have had no certainty about the outcome and therefore could never have fully determined it.

${ }^{11}$ Unless we are to think that Creon misreported the oracle, misled by the witness's untruth (122-3).

${ }_{12}$ Particularly as the text oscillates between singular and plural: e.g. at 102, 107, 108, 122-3, 124 .

${ }^{13}$ Though Griffith (1996: 60) thinks that in the course of such an interrogation the witness would have been forced to divulge that Oedipus killed Laius.

${ }^{14}$ E.g. Kitto 1961: 139; Cameron 1968: 67-69. On the irony of the Corinthian's entrance see Seale 1982: 237: 'There is a sudden waywardness about the action which contrasts noticeably with the planned
} 
Meanwhile the truth has emerged from the lips of Teiresias but Oedipus is in no condition to receive it. ${ }^{15}$ We note here the seer's claim that Apollo is working, presumably through overdetermining events, to destroy Oedipus (376). With the reunion of the two shepherds, Oedipus has all he needs to discover the truth, and here it is clear that only the concept of a divinely imposed destiny could make sense of his life - the prophecies given to his parents and to him, fulfilled by the mortals' very attempts to evade them; his miraculous salvation by the man who was later to be the sole survivor of the incident at the crossroads and by the man who was later to bring the news of his adoptive father's death; the classificatory and 'mathematical' absurdities produced by the incest. ${ }^{16}$ There are too many 'coincidences' to permit a purely dramaturgical interpretation. Reality here is not some passive material, like Democritus' atoms, fully conformable to human reason, but the shaping of an at least minimally personal god who interacts with mortals. ${ }^{17}$ Moreover, it is diachronic, a mysteriously patterned and unique sequence of events rather than a permanent dynamic of scientifically predictable laws. Such absurdity is not perhaps typical of all human life, but remains a possibility. Hence the play 'is one of the most revealing documents of Western man's determination to define self-knowledge in intellectual and rational terms, and one of the most powerful statements of the limitations of the enterprise.'18

Although the self-blinding is not predicted by the oracles, it is predicted by Teiresias, so Apollo foresees it. Is it then part of Oedipus' destiny? R. P. WinningtonIngram has an excellent analysis of the relevant passage. ${ }^{19}$ When, earlier in the piece, Oedipus fears that he may be Laius' killer he calls himself echthrodaimon (god- or daimon-hated) (816) and imputes the calamity to a cruel daimon (828). In the present passage, the chorus ask him what madness came on him and what daimon leapt upon his moira (destiny) 'that was already characterised by a negative daimon' (dysdaimoni, 1302), and Oedipus himself remarks on how far his daimon has sprung (hin' exelou,

appearances of Creon and Teiresias and which actually sets back Oedipus' latest arrangement, the arrival of the herdsman.' Indeed, Seale (1982: 238) sees in it 'the sense of a pursuing doom, of a fiendish game in which appearance actively seeks out its victim' [Seale's italics].

${ }^{15} \mathrm{He}$ cannot accept it, in part because of the cryptic way in which the information is conveyed, but more due to the outrageous content of the revelation which is even harder to accept because it does not emerge in a logical manner as the end-product of an empirical investigation. Lefèvre 1987 passim, makes much of Oedipus' alleged tardiness in putting together the pieces of the puzzle.

16 'Such a fantastic series of coincidences [in Oedipus' life] seems expressly designed to mock the idea that human destiny is predictable; it is a paradigm of the inconsequent anarchy of the universe' (Knox 1957: 179). 'Oedipus founds his innocence on a basic law of noncontradiction, the fundamental logic in man's apprehension of reality. Here, however, noncontradiction gives way to a fantastic, irrational "logic" of paradoxes in which opposites can in fact be equal and "one" can simultaneously be "many"' (Segal 1995: 216). In a later book, Segal (2001: 62) points to patterns of return in Oedipus' life: the two shepherds came together in his infancy and again at the revelation; Oedipus returns to the furrows of his mother (1403-8); Laius tries to get rid of his son but he comes back to kill him; the oracle to Laius returns, assuming different forms in Oedipus' youth and maturity. 'Sophocles does not use these coincidences as proof of a deterministic universe, but rather as the facts of an uncanny pattern of a life that is thus marked as tragic.'

17 'The idea that men in some way, invariably misunderstood, behind their immediate conflict with other men, are really engaged with the gods, is a general condition for all Greek tragedy. Some plays are explicit about this early, some at different points in the course of the action, and some quite late' (Cameron 1968: 46).

18 Segal 1995: 142.

${ }_{19}$ Winnington-Ingram 1980: 173-8. 
1311) (i.e. to the extent of the self-blinding). It would seem then that Oedipus' destiny has been further extended, in a sense through an external supernatural agent, but also through his own character, since after the self-blinding Oedipus informs the chorus that, while Apollo brought to pass 'these sufferings of mine' (1330), ${ }^{20}$ he struck his eyes with his own hand because there was nothing pleasurable for him to see.

\section{III}

We have seen that Apollo does indeed work towards the fulfilment of Oedipus' destiny through the communication of oracles which require a human response for their fulfilment and immanently through such external events as the 'coincidence' of the Corinthian's timely arrival. It seems reasonable then to infer that the god is responsible for the multitude of ironies and coincidences that inform the events and that he works through the mind of Oedipus, at least during the events surrounding the selfblinding. ${ }^{21}$ We do not know if he actually decreed Oedipus' destiny or if, as a god of prophecy, he was intent on predicting it and for that reason became involved in assisting its fulfilment. Since Apollo's predictions are causally inseparable from their

\footnotetext{
20 'The main reason why "it was Apollo" for Oedipus is simply that, as no one could deny, what Apollo had decreed had come to pass' (Parker 1999: 17). It is reasonable (to the archaic mind) to think that a god who predicts a destiny also brings it about.

${ }^{21}$ Strangely enough, this conclusion is sometimes denied. No less a critic than Knox (e.g., at 1984: 150; also 1957: 33) insists that Apollo does nothing more than utter the oracles. This allows Knox to regard Oedipus as fully free during the onstage action: 'This presentation of the hero's freedom and responsibility in the context of the dreadful prophecy already unwittingly and unwillingly fulfilled is an artistic juxtaposition, a momentary illusion of full reconciliation between the two mighty opposites, freedom and destiny. It is an illusion because of course the question of responsibility for what happened before the play, of Oedipus' freedom in the context of divine prophecies fulfilled, is evaded.' On the contrary, there is overdetermination before and during the onstage events: Oedipus' destiny is the joint product of his character and Apollo's immanent intervention throughout. Freedom and destiny are not antithetical concepts in Sophoclean tragedy. See also Whitman 1951: 141-2. Kitto (1961: 139), another distinguished critic, similarly intent on preserving Oedipus' autonomy, speaks of two planes of action, one involving the gods and the other the humans. Unfortunately, this suggests that the gods operate separately from the mortals and does not allow for immanent interaction. If the gods are not in some sense guiding or penetrating the thoughts and events in the human world, what is the point of their acting them out on another level? Is such an idea even intelligible? (It would be absurd to say that the gods of the Iliad enact the human events of the epic simultaneously on Olympus.) As Cameron (1968: 79) rejoins, the concept of planes is 'a way of maintaining the idea of the play itself as an exclusively human action, and smuggling the gods in at the same time.' Some critics go even further, identifying the daimon (after Heraclitus) largely with Oedipus' ethos. E.g., Versényi (1974: 224-25), who minimises external circumstances to identify the causation with the unfolding of Oedipus' nature. Euben (1990: 105) more moderately takes the view that Oedipus' fate 'becomes real only through the action of his character, that he is made by the destiny he helps fashion.' Landfester (1990: 62) sees suffering in the play as entirely a product of the misuse of human freedom, as if there were right choices open to Oedipus. And, in a sense, the external circumstances are indeed generated to a major degree by Oedipus' choices. Had he returned to Corinth he would not have committed parricide and incest, but the situation is complicated by the fact that the oracle intervenes in the causation so that Oedipus responds to it. The reality too of divine immanence and purpose renders it implausible to argue that his destiny is generated entirely by his character. Indeed Landfester (1990: 62) proceeds to mitigate this position by speaking of mortals 'codetermining' ('mitbestimmen' [his italics]) their fates.
} 
fulfilment, it is difficult to imagine that the god is not indeed intent on that fulfilment. If we knew that predicting a particular event to a person was a precondition of its fulfilment, we should hardly proceed to predict it unless we desired its fulfilment. That Apollo is so committed seems a reasonable inference also from his traditional roles as god of self-knowledge (as mentioned above) and of plague and healing, since the oracles launch Oedipus on what turns out to be a quest for self-discovery and the salvation of Thebes. ${ }^{22}$

But to return to the question of the god's purpose, is Oedipus guilty of some specific offence? We begin with his response to the oracle he received at Delphi. In the confines of the peculiar world of Aeschylean and Sophoclean tragedy in which the fulfilment of divine prophecies and divinely executed curses is inevitable, it is simply irrational for characters to attempt to evade their destinies. This truth impacts powerfully on Eteocles in Aeschylus' Seven. He knows that the curse must be fulfilled and therefore his only rational course of action is to embrace that fulfilment as bravely as he can, but to do that he has to ignore or insanely embrace the pollution incurred by fratricide (Aes. Th. 653-719). ${ }^{23}$ Oedipus, on the other hand, reacts quite irrationally, though also quite understandably - and roughly in the way in which Aeschylus' chorus would have liked Eteocles to have reacted. First of all, he ignores his continuing uncertainty about the identity of his parents and simply assumes that Polybus and Merope are indeed those parents. (The chorus of the Seven want Eteocles to persuade himself that the daimon might in time become less intent on fulfilling the curse: Aes. Th. 705-8). This is a little surprising in view of his later uncertainty (with Teiresias at 437). He then proceeds to avoid them, thereby running into his real parents, first of all his father at the crossroads and later his mother in Thebes.

Is he at fault in this? Griffith thinks that Oedipus should have asked the oracle for clarification as Croesus was criticised for failing to do at Hdt 1.91.4, ${ }^{24}$ but since Croesus' oracle was conditional (if he attacked the Persians he would destroy a great empire), being told what empire was meant would have made him cancel the attempt. Moreover, Croesus is castigated by a perhaps defensive Delphi for not making the further inquiry because he is himself castigating the oracle for not originally volunteering the information. We cannot infer from this a universal responsibility to ask for clarification of oracles, particularly since the point of an oracle is not infrequently to present the recipient with an enigmatic statement which he must himself unravel, if he can. (The oracle in the Trachiniae about finding peace is a case in point, and there is never any suggestion that Heracles should have asked what was meant or that he would have been informed if he had.) But Oedipus' oracle is unconditional, so further clarification would have been pointless. If Apollo had told him the true identity of his parents, the oracle would not have been fulfilled. But in that case it would never have been uttered. The issue of seeking further clarification aside, Oedipus' response was nevertheless doubly irrational in the attempt to avoid what must hap-

\footnotetext{
${ }^{22}$ On self-knowledge and the link to the motto Know Yourself, see Cameron 1968: 16-17. On the plague see Scodel 1984: 68: 'Though Apollo is never explicitly called the sender of the plague, he is a god of plague. The plague is not simply a result of the ritually polluting presence of Oedipus, coming when he has ruled for so long; it is a divine intervention, arbitrary as such can be - the god acts when he will.' Also Schwartz 1986: 196. For a contrary view see Knox 1957: 9-10.

${ }^{23}$ See Lawrence 2007.

${ }^{24}$ Griffith 1996: 52.
} 
pen and in the assumption that Polybus and Merope must be his parents, but it would be misleading to insist that the oracle would not have been fulfilled had he returned to Corinth and simply taken what would have been ironically unnecessary care not to kill Polybus or to marry Merope. True enough, it would not have been fulfilled, but again since Sophoclean oracles are infallible no such oracle would ever have been uttered. Are we to say then that Apollo uttered this oracle knowing that it would be fulfilled because Oedipus, showing his native impulsiveness, would respond as he did? At least this would be consistent with the text, though it is of course never explicit.

It is hard to judge the actions of a person who is reacting to the true belief that he is fated to commit terrible crimes because we do not live in a world in which such a possibility exists. While passive acceptance of the prophecy, which entails, paradoxically, ignoring it and getting on with life is the only rational course, the psychologically natural course is clearly an irrational attempt to evade fulfilment. While to Greek religious sensibilities attempts to evade divine prophecy are doubtless futile, they do not seem to be impious. On the contrary, strictly irrational though it is, it might seem impious not to seek to avoid a fate that entails pollution. This, at any rate, is the view of Aeschylus' chorus in the Seven.

Oedipus' failure to respond logically is often seized upon by those critics who would impugn his intelligence, arguing that insofar as he creates his own destiny he does so through errors of judgement which are a product of his personal inadequacies rather than inevitable products of being human. Incredibly, some of this criticism seems to assume that it was logically possible for Oedipus to avoid his stated destiny. H. Erbse criticises Oedipus not only for not following up the allegation and so doubting his Corinthian parentage, but also for killing a man who could have been his father and marrying a woman who could have been his mother. ${ }^{25}$ Erbse sees this as an example of overhasty and overconfident action and thinks that Oedipus should have deliberated more and acted more rationally and adapted to the world as determined by the gods in harmony with the injunction to self-knowledge. He tries to support his case with the parallel of Creon in Antigone, pointing out that, like Oedipus, Creon ignores advice. ${ }^{26}$ But the advice Oedipus ignores is to abandon his search for the killer which the god has instructed him to pursue and upon which the salvation of Thebes depends - effectively the search for self-knowledge. No advice whatever could have diverted him from his destiny. Both men attain a form of self-knowledge, but Creon's is moral rather than existential, and therefore closely relates to defects of character. Flaws in Oedipus' judgement are undoubtedly to be found in the text, but it is surely significant that awareness of them never constitutes an aspect of his self-knowledge. Heracles in the Trachiniae similarly fails to realise the contribution to his predicament of his own lustful and violent character, though here the nexus between character and destiny is, if anything, somewhat closer than in the case of Oedipus.Oedipus makes a number of errors of judgement in the play (most of which merely temporarily divert him from self-discovery), and those who would minimise them can argue that they are necessary plot contrivances rather than indi-

\footnotetext{
${ }^{25}$ Erbse 1993: 60.

${ }^{26}$ Erbse 1993: 61.
} 
cations of character, and it is indeed easy to see that if Sophocles had eliminated them he would have had to contrive a radically different plot. As Scodel remarks,

...the basic dramatic problem is to delay Oedipus's discovery without straining credibility or allowing Oedipus, the great solver of riddles, to appear a fool. In part audience good will is required: we accept that he cannot find out too soon and take pleasure in the constant ironies. ${ }^{27}$

But what of Oedipus' reactions at the crossroads? According to Oedipus, as he approached Laius' party,

I was met by a herald (kerux, 802) and a man riding in a wagon....and the leader (hegemon, 804) and the old man himself tried to drive me from the road by force. In anger I struck the driver (trochelaten, 806), the man who was trying to turn me back; and when the old man saw it, he waited till I was passing his chariot, and struck me right on the head with his double-pointed goad. Yet he paid the penalty with interest; in a word, this hand struck him with a stick, and he rolled backwards right out of the wagon, and I killed them all (802-13, tr. Lloyd-Jones).

The pattern is clear: Oedipus twice reacts (perhaps overreacts) to provocation.

There is a vagueness about the number of people involved. Are the herald and the leader one and the same? The driver is presumably distinct from the herald against whom Oedipus does not use violence in the first instance. (When he 'kills them all' the situation has changed significantly.)

Now Oedipus, in the view of Griffith should have given way on the grounds of Laius' rank (evident in his mode of travel) and age, and because he was a stranger. ${ }^{28}$ Also heralds are inviolable and this one must have been recognisable by his caduceus ${ }^{29}$ (But Oedipus, as we saw, does not strike the herald at first.) Gregory, however, while agreeing that precedence was determined by status, argues that Laius' party did not indicate its rank (contrast Eur. Phoen. 40), while Oedipus would have been used to thinking of himself as being of very high status indeed; Oedipus was unable 'to identify Laius as royal by visual means, since the king was not accompanied by the sizable retinue appropriate to an aner archegetes'. ${ }^{30}$ We might rejoin, in support of Griffith, that the famously intelligent Oedipus might still have drawn some pertinent conclusions from what he could see. Perhaps then, as Griffith maintains, Oedipus should have stopped to think, and that he did not do so is a moral failing that resulted in a massacre. ${ }^{31}$ Laius' blow to Oedipus' head was only the next stage in a natural escalation of the violence which Oedipus had fuelled by retaliating (though in a culturally acceptable way?) against the driver. We do not know how much injury Laius inflicted, though Oedipus was clearly not at all incapacitated by it. Oedipus' climactic reaction (the massacre) he himself describes as an 'unequal' punishment, but, realistically, we have to consider the danger in which he now

\footnotetext{
27 Scodel 1984: 63.

${ }^{28}$ Griffith 1992: 197-9; 1996: 49.

${ }^{29}$ Griffith 1992: 200 and 1996: 49.

${ }^{30}$ Gregory 1995: 145. See Schmitt 1988: 22 on the importance to Oedipus of avoiding shame.

${ }^{31}$ Griffith 1992: 200 f.
} 
found himself. ${ }^{32}$ If he had desisted at the point when Laius lay sprawled on the ground perhaps with significant injuries and certainly severely dishonoured, could Oedipus have escaped with his life?

Now in the Attic law of the time of the play's performance (and thus a relevant criterion of judgement in the eyes of the original audience) self-defence 'was a mitigating circumstance in a case of intentional homicide, rather than grounds for lawful homicide....Yet Oedipus does not argue self-defense, claiming, as he would have to do, that Laius was about to kill him, stating in fact that on this occasion Laius wanted only to drive him from the road (805)'..$^{33}$

That Oedipus was in general confrontational and overreacted would have been clear enough to the audience, and they were free to draw the appropriate moral conclusions, taking perhaps a more lenient view than we would take. We realise by this point in the play (after the debacle over Teiresias and Creon) that Oedipus is prone to overreact and that if he is given free rein the consequences can be morally deplorable. (He only refrains from killing Creon through the intervention of the chorus and Jocasta and because events move on.) What we see here then is how the flaws in Oedipus' character make a necessary (but not sufficient) contribution to the fulfilment of his destiny. And in favour of those critics who find Oedipus' morally culpable we have to admit that Sophocles does not attempt to depict him as flawless. The significance of these flaws though is another question. Oedipus

is led to his crime because he has the Sophoclean hero's impulsive incapacity to yield....Read this trait as hubris or heroism. ${ }^{34}$

Oedipus' error is partly a product of unavoidable ignorance - he does not and could not be expected to realise that Laius is his father. ${ }^{35}$ But it is also moral, because he would not have killed Laius qua human being (let alone father) had he exercised proper circumspection rather than being carried away by anger. However, none of the characters ever attempts either to condemn or to justify Oedipus' behaviour at the crossroads. Still less is it suggested that he should have been more careful in light of the oracle. ${ }^{36}$ The context of the story's narration suggests that its predominant importance is whether this episode could possibly be one and the same as that in which Laius was reportedly killed, since there was supposedly one survivor in that case and more than one killer of Laius. In sum then, although Oedipus' character is in evi-

\footnotetext{
32 The dangers of the situation apart, also to be allowed for perhaps is the idea that it is 'dikaios for the striker of the first blow to be killed in retaliation (this notion, which we might call "a head for an eye", takes account, unlike "an eye for an eye", of the injured man's feelings as a distinct ingredient of the situation which needs to be rectified)' (Dover 1974: 184).

${ }^{33}$ Griffith 1992: 196-7 and 1996: 47, 50.

${ }^{34}$ Griffith 1996: 51.

${ }^{35}$ But Griffith (1996: 52) finds him guilty of culpable negligence in not continuing the search for his father's identity or embarking on 'a life of non-violence and celibacy.' But this ignores the inevitability of the oracle's fulfilment.

${ }^{36}$ The play 'carefully avoids the suggestion that Oedipus is "justly" punished for either his own or his parents' wrong-doing. Of course he has his faults - hot temper, a certain cocksureness in judgement but they are far outweighed by his virtues. In the critical affair at the cross-roads he was not the cause but the victim of the aggression' (Kitto 1958: 58).
} 
dence in this incident and therefore a relevant factor, his guilt is at least mitigated by the behaviour of Laius' party.

In the course of the play Oedipus has demonstrated character flaws before we hear details of the parricide. There is the impulsive anger and resulting unjust abuse of Teiresias and soon Creon too. But through these events Sophocles establishes a pattern whereby Oedipus' flaws emerge only reactively and often understandably. The course of the scene with Teiresias makes it abundantly clear and sympathetically understandable why Oedipus gets angry with him and then with Creon, even though unjustifiably. This pattern is carried over into the road rage incident. These are all offences of varying degrees of seriousness against human beings. A god is much more likely to be angered by an offence against his own honour, and this brings us to Oedipus' temporary belief in a random universe. If the offence lies here, Apollo must have set up the parricide and incest in anticipation. As it begins to seem that Oedipus' oracles are untrue, Iocasta advocates living at random in a random universe presided over by the 'goddess' Tyche (977-83). Oedipus enthusiastically agrees, but only because he has such a strong vested interest in disbelieving in Apollo's oracles. The implications of such disbelief are more radical than Oedipus and Iocasta realise.

These implications have already been explored in the second stasimon (863910) where the chorus refer to laws of eternal validity generated by the Olympian gods (863-72). Hubris, they go on to say, begets the tyrant and comes to a bad end (873-9), but 'I pray the god never to undo the wrestler's throw that brought good to the city' (879-81, tr. Lloyd-Jones). Since the chorus sympathise with Oedipus, it is natural to relate this prayer to the solution of the Sphinx's riddle: may the gods never bring Oedipus down or his achievements to nought. Despite the king's high-handed treatment of Teiresias and Creon, he is not the hubristic tyrant to whom they refer. The chorus continue:

But if a man moves arrogantly in deed or word, without fear of Justice, and without reverence for the seats of the gods, may an evil fate take him, for his ill-starred pride, if he will not win advantage justly and keep himself from acts irreverent, or if he wantonly lays hands on things inviolate! In such a case, what man shall successfully ward off the shafts of passion? For if such actions are to win respect, why should we honour the gods with dances? (883-96, tr. Lloyd-Jones)

None of this applies to Oedipus. ${ }^{37}$ Though he lays his hands on his inviolate parents he does not do so intentionally, let alone 'wantonly.' Certainly he is guilty of arrogant words, but he is hardly 'without fear of Justice, and without reverence for the seats of the gods.' The chorus go on to pray to Zeus that oracles be vindicated, but their panic is unnecessary:

....already the oracles of Laius are fading and being expunged, and nowhere is Apollo manifest in honour; but the power of the gods is perishing (906-10).

\footnotetext{
${ }^{37}$ Schmitt (1988: 24) thinks the chorus have accepted Oedipus' conspiracy theory and have Creon in mind!
} 
The first clause would be true enough if Jocasta was right (707-9), but she was careful to dissociate prophecies from their alleged divine origin (711-12), and the celebration of Tyche (977-8) is yet to come. In any case, Apollo's vindication is restricted to the truth of his oracles. ${ }^{38}$ There is nothing in this ode to suggest that Oedipus deserved his fate.

\section{IV}

If there is no specific offence, is Apollo concerned to remind Oedipus of his mortal status? Many of the play's dramatic techniques and much of its impact are concerned with the contrast between Oedipus' seeming prosperity and the reality of his pollution. It is a theme familiar from Herodotus that prosperity is precarious; this play goes a step further in presenting it as illusory. The grandeur of Oedipus' seeming prosperity makes him an excellent specimen for the illustration of this idea. The strong sense of divine immanence conveyed by the oracles and by the only apparently coincidental events implies that the Apolline will is more than a mere metaphor for the way things are. ${ }^{39}$ As in Herodotus, there is a disturbing, if little more than subliminal, sense of divine malice or phthonos.

That the divine malice (if such it is) against Oedipus is general rather than personal is supported by his innocence of any specific offence. It is supported too by the traditional and general nature of his self-knowledge. While we can see how Oedipus' character has contributed to his destiny, it is never presented as the real or at least predominant cause of it - unlike Ajax's, or Creon's in the Antigone. What Oedipus learns are the facts of his identity and the consequent pollution, and his selfloathing is based on his existential status; it has nothing to do with guilt over a voluntary moral transgression.

That Apollo should desire the disclosure of Oedipus' destiny is only to be expected. A human doctor actually deplores the grave illness whose existence he feels obliged to disclose to his patient; and Apollo, like the human doctor, is, qua revealer and healer, committed to revelation and healing. Oedipus and Thebes, perhaps even more than the gravely ill patient, need to know. But this is not to attribute to Apollo

\footnotetext{
${ }^{38}$ Lesky (1965: 116) believes here that 'the poet's deep faith in the greatness and the wisdom of his gods remains unshaken,' but the ode does nothing to vindicate divine wisdom.

${ }^{39}$ As Scodel (1984: 68) contends, 'Oedipus's character is necessary for the disaster, and he acts freely both within the drama and in the events he recounts. He is no puppet. Still we cannot say that Apollo has no essential part in what happens to Oedipus. The oracles are a truth outside time, and Apollo's knowledge of what will happen does not imply that he wills the events. Apollo, however, does not merely know the future, but also imparts his knowledge, and not mechanically, but according to his will. Early in the play, Oedipus reminds the chorus that no man can force a god (280-81). When he realizes that he may have killed Laius, he joins this fear with the fact that he cannot return to Corinth for fear of the oracle, attributing this fear to a "cruel divinity" (828-29). The following prayer, in which he twice prays not to "see" such disaster (830-34) will be in a sense answered by the self-blinding; gods who answer prayer thus seem cruel indeed.' Contrast, e.g., Reinhardt (1979: 134) who denies that the play is concerned with the attribution of moral responsibility rather than with truth and illusion. Similarly, Gellie (1972: 105) states that 'it is not the murder and the marriage that destroy Oedipus; it is the discovery. He is destroyed by the truth, and Apollo cannot be blamed for knowing, or being, the truth.' But that is like saying that a terminally ill person is destroyed by the knowledge of that fact rather than by the fact itself.
} 
the compassionate concern of a human doctor. The self-knowledge the gods wish us to have usually concerns our vulnerability and insignificance as compared to themselves, and it is possible that we are to imagine that Apollo wants to bring the great Oedipus down to size and therefore does approve of his destiny (whether his motive is an impersonal concern to preserve the proper boundaries between gods and men or a more self-centred phthonos. $)^{40}$

If we allow the legitimacy of questioning the justice of Oedipus' sufferings, can we speak with Parker, in the words quoted at the outset, of 'the ultimate incomprehensibility to mortals of the divine world? And if so, if the ways of the gods are incomprehensible, is that because those ways are good, but human comprehension weak? Or because mortals seek justice where none is to be found?'41 A number of scholars see in the play an inscrutable, perhaps cruel, but still mysteriously ordered universe which must be accepted and even respected, even if its justice is not readily intelligible. ${ }^{42}$ For example, Sophocles, according to Kirkwood, 'presents deity as being in harmony with ultimate justice; we are left with the feeling that the universe is not all chance and cruelty but that behind the enigmatic region of doxa there is an abiding and just moral order. ${ }^{43}$ And Kitto, who is prepared to be more specific, speaks of a cosmic Dike which is not human justice but a kind of principle of compensation or balance, reminiscent perhaps of the cosmic compensation of Ajax's deception speech (Aj. 668-77). The basic idea 'is that dike, the regular order of things, may be contravened for a time, but in the end it must reassert itself'. ${ }^{44}$ This human universe 'is not a machine operated by some external force; it is a system of human action which has its own inherent laws, and the laws are within the administration of the gods.' Such gods may not command our love 'but they must command our respect'. ${ }^{45}$ The sheer existence of oracles implies that the human universe is not chaotic and therefore without meaning or value, but is obedient to law and therefore capable of being reasoned about, so far as human reason can go.' ${ }^{\prime 46}$ The dramatist sees the world as based on logos 'which includes human reason but vastly transcends it.' ${ }^{4}$

Kitto's concept of dike would provide some broader theoretical explanation as to why the parricide and incest create a pollution and why the polluting person must be exposed and exiled. If there is 'justice' here, then it cannot be what we normally mean by the term; it can only be a principle of impersonal compensation that acts in the interests of the cosmos and of society without concern for the individual. But none of this explains why Laius and Oedipus were singled out for such roles in the

\footnotetext{
${ }^{40}$ Cf. the argument of Iris at Her. 827-42.

${ }^{41}$ Parker 1999: 26.

${ }^{42}$ Gellie (1972: 105) sees the universe but not Apollo as cruel. Dodds (1966: 47) claims that there is a world order we must respect but not expect to understand or justify in terms of our notions of justice. For Buxton (1980: 36), 'The gods' will may be hard for mortals to fathom, and it may not match human notions of what is just, but the gods are indisputably there.' For Parker (1999: 25), 'What vindication of the gods amounts to in Sophocles is very far from a Leibnizian demonstration that we live in the best, or even the justest, of all possible worlds, with all that such an argument implies about a full and rational understanding of the purposes of the gods and of the workings of the world.'

${ }^{43}$ Kirkwood 1958: 287.

${ }^{44}$ Kitto 1958: 49.

${ }^{45}$ Kitto 1958: $50 \mathrm{f}$.

46 Kitto 1958: 55.

${ }^{47}$ Kitto 1958: 62.
} 
first place, so that we are left still with a sense of the arbitrary and absurd, a point well brought out by Versényi for whom Sophocles 'no longer demands that the gods conform to man's idea of justice and rationality but lets divinity stand as an irreducible element of darkness, mystery, and even absurdity in the human world.' 48 Oedipus 'exalts himself by his own almost superhuman effort and attains an awesome and terrible dignity through self-affirmation, i.e., through the affirmation of his own failing, agonizing, and "ultimately" meaningless destiny.' 49

For Gould such absurdity testifies to a parallel, if partially intersecting, universe, an alien divine world.

...Oedipus's belonging not wholly among men but also to an alien world, outside our understanding, mocking the order, the rules and values of human society, yet having its own coherence, its own logic of irony and coincidence - that is the central image of Sophocles' play.... This, and not the driving force of fate nor the issues of human or divine justice, is Sophocles' concern in King Oedipus and the true kernel of his religious statement. ${ }^{50}$

But Gould exaggerates the disjunction between the human and the divine realms. The Greeks were predisposed to find an immanent logos in a single universe, and the religious and mythological basis of the literary tradition in which Sophocles was writing fostered that tradition's commitment to the idea of an ultimate order, insofar as the processes of nature and even the lives of some human individuals are eternally fixed by moira and largely unalterable by the Olympian gods, while these gods themselves reflect the essential order of human society in that they are organised in a family and respect at least some of the moral rules that apply to humans. ${ }^{51} \mathrm{But}$ a universe so arranged still leaves room for a limited disorder in the lives of human beings which can be embodied in their strange destinies. After all, even the modern secular Western world view combines an ordered and (more or less) scientifically intelligible universe with the apparently disordered and morally problematical lives of individuals.

Oedipus' destiny is undoubtedly patterned in some way and, as Segal observes, some readers have remarked on 'the orderliness of the mental world' which the play's structure exemplifies, while others 'have emphasized the contrast between the formal beauty of the play's logical design and the frightening role of chance and necessity in its contents. ${ }^{\prime 2}$ There is no contrast here, however, as far as concerns necessity (which naturally harmonises with design), and chance is eliminated or at least subsumed under that necessity and the Apolline immanence. ${ }^{53}$ Segal however thinks that the play 'forces us to consider both the order-imposing power of art and the ar-

\footnotetext{
${ }^{48}$ Versényi 1974: 231-2.

${ }^{49}$ Versényi 1974: 233.

${ }^{50}$ Gould 1988: 160.

51 The Homeric Zeus, e.g., at Iliad 1.500-30, respects the claims of Thetis as a suppliant and as a person from whom he has received a charis. In spite of his reluctance to incur his wife's wrath, he undertakes to reciprocate and swears an unbreakable oath to that effect.

52 Segal 1995: 142.

${ }^{53}$ Griffith (1996: 62) accords chance a significant role in order to preserve free will which, as we have seen, is problematical.
} 
bitrariness of that imposition. ${ }^{54}$ He sees the play, anachronistically, as being selfreflexively (and self-reflectingly) 'about the origins of its own writing, that is, about the modes of representation through which the work of art imposes order upon experience in such a way that the disorder always remains a part of the order....The very perfection of the formal design of the plot sets off the disturbing imperfection of the world that the plot creates. ${ }^{\prime 55}$ But disorder is hardly a striking feature of the world of this play, and Segal's paradox works much better for Euripides' Heracles in which a carefully designed, though sensationally unorthodox, structure ultimately reflects a universe dominated by sheer Tyche.

But is there any comfort to be had in knowing that the world is ordered, even if incomprehensibly so? Not according to Buxton:

A feature of many plays called 'tragedies' is the sense they convey of the presence of a metaphysical structure informing and conferring significance on events, combined with a sense both of the failure of humans to grasp that structure, and of the inadequacy of the structure ultimately to be a comforting and sustaining element in human life.... In ancient Greece, the metaphysical structure is at its clearest in Bacchae, Hippolytus, and Eumenides, a good deal more opaque in Women of Trachis and Agamemnon; variable, too, is the quality of 'sustenance' proferred. But nowhere, I think, is the opacity more enshroudingly present, the solace harder to be sure about, than in Oedipus Rex..$^{56}$

It has been suggested that the sheer order implied by the existence of the infallible Apolline prophecies makes Oedipus' disastrous life at least minimally bearable, ${ }^{57}$ and there is allegedly some comfort for the rest of us in the apparent vindication of the divine order called into question in the second stasimon (863-910).

There is no evidence of justice in any meaningful sense in this absurdly ordered universe. While Sophocles, unlike Euripides in his Heracles, does not explicitly impugn divine morality, he does a great deal to suggest that Oedipus' fate is unjust by human standards (and what other standard is meaningful to us?). In particular he aggravates his hero's sufferings by denying him the comfort of declaring, as Euripides' Heracles does, his moral innocence and having that self-view validated by his peers. ${ }^{58}$ In the Coloneus, most forcefully at 960-1002, the poet allows Oedipus to defend his role in the parricide and incest, but he is forbidden that consolation here perhaps because Sophocles is intent on maximising his isolation and distress. Creon, though not vindictive, is not particularly sympathetic, and the best the chorus can offer by way of support is to tell Oedipus that they wish he had never been born and to suggest that suicide would have been a better option than blindness (1367). If Oedipus is correct

\footnotetext{
${ }^{54}$ Segal 1995: 142. This is not too far from the view of Peradotto (1992 passim), who declines to play by the rules which require us to accept the metaphysical presuppositions of the play. For a critique of his view see Griffith 1996: 59-65.

55 Segal 1995: 143.

${ }^{56}$ Buxton 1996: 42-3.

57 'The existence of the prophecy is the only thing that makes the discovery of the truth bearable, not only for us but for Oedipus himself.' Oedipus' one consolation is 'the fact of divine prescience demonstrated by the existence of the original prophecy' (Knox 1957: 43).

${ }^{58}$ Oedipus, unlike the Euripidean Heracles, does not rail against the gods, 'much though moderns have complained on his behalf' (Parker 1999: 24).
} 
in claiming that the gods hate him (1345-6), his existential value in the scheme of things is actually less than the zero worth the chorus place on the generations of men (1186-8). He can take no moral comfort from believing that the gods approve of his good intentions. Divine morality is effectively impugned by the gods' amoral attitude towards Oedipus.

Bernard Knox, in an influential view of the play, argues that we see in Oedipus 'the catastrophe of fifth-century man; all his furious energy and intellectual daring drive him on to this terrible discovery of his fundamental ignorance - he is not the measure of all things but the thing measured and found wanting. ${ }^{59}$ Knox goes on to observe: 'the force with which Oedipus now reasserts his presence springs from the truth he now understands: that the universe is not a field for the play of blind chance, and that man is not its measure. This knowledge gives him a new strength which sustains him in his misery and gives him the courage needed to go on living, though he is now an outcast, a man from whom his fellow-men recoil in horror.' ${ }^{60}$ But surely Oedipus' renewed strength and courage testify to his characteristic virtues which actually invalidate the divine assessment of his worth. After the anagnorisis Oedipus is 'measured' negatively by the gods, by the other characters, by the society and by himself, but the audience cannot fail to observe the nobility of his acceptance of his new status. In a similar paradox, just as Socrates knows that he knows nothing, so Oedipus nobly accepts his complete worthlessness. The final measure of Oedipus is not divine but indeed human. ${ }^{61}$ As at the conclusion of Euripides' Heracles, though only implicitly and much more subtly, the divine purpose (or at least the divine will as minimally implied by events) is presented as being tragically at odds with the worth of the human victim. ${ }^{62}$

\author{
Dr. Stuart Lawrence \\ Classical Studies, Massey University \\ E-mail: S.E.Lawrence@massey.ac.nz
}

\footnotetext{
${ }^{59}$ Knox 1984: 143.

${ }^{60}$ Knox 1984: 152.

${ }^{61}$ The irrelevance to human affairs of the divine moral perspective is more evident in Ajax in which Odysseus refrains from joining Athena in her Schadenfreude at the hero's expense (121-26) and later defends the right of his former enemy to win burial. The goddess's condemnation of Ajax relates to his attitude towards her but is largely irrelevant to his virtues and vices in the eyes of his peers.

${ }^{62}$ Heracles' personal worth is strongly insisted upon in the final scene of the play, especially by the hero himself, while Zeus and Hera are roundly condemned (Zeus throughout the play) for injustice and insensitivity to human moral concerns. None of this is explicit in Sophocles; on the contrary Oedipus insists on evaluating himself (negatively) in the non-moral, existential terms which the gods themselves would presumably employ.
}

I would like to thank the anonymous readers of SHT for their comments on an earlier draft of this paper. 


\section{BIBLIOGRAPHY}

Buxton, R. G. A. (1980) 'Blindness and Limits: Sophokles and the Logic of Myth.' JHS 100, 22-37.

Buxton, R. G. A. (1996) 'What can you rely on in Oedipus Rex,' - Silk, M. S. (ed.), Greek Tragedy and the Tragic: Greek Theatre and Beyond. Oxford: Clarendon Press, 38-48.

Cameron, A. (1968) The Identity of Oedipus the King. New York: University Press.

Dodds, E. R. (1966) 'On Misunderstanding the Oedipus Rex.' - GER 13, 37-49.

Dover, K. J. (1974) Greek Popular Morality in the Time of Plato and Aristotle. Oxford: Blackwell.

Erbse, H. (1993) 'Sophokles über die geistige Blindheit der Menschen.' - ICS 28, 57-71.

Euben, J. P. (1990) The Tragedy of Political Theory. The Road not Taken. Princeton: Princeton University Press.

Gellie, G. H. (1972) Sophocles. A Reading. Melbourne: Melbourne University Press.

Gould, J. (1988) 'The Language of Oedipus.' - Bloom, H. (ed.), Sophocles' Oedipus Rex. New York; New Haven, Philadelphia: Chelsea House Publishers, 143-60.

Gregory, J. W. (1995) 'The Encounter at the Crossroads in Sophocles' Oedipus Tyrannus.' - JHS 115, 141-6.

Griffith, R. D. (1992) 'Asserting Eternal Providence: Theodicy in Sophocles' Oedipus the King.' - ICS 17, 193-211.

Griffith, R. D. (1996) The Theatre of Apollo. Divine Justice and Sophocles' Oedipus the King. Montreal: McGill-Queen's University Press.

Hutchinson, G. O. (1999) 'Sophocles and Time.' - Griffin, J. (ed.), Sophocles Revisited. Oxford: Oxford University Press, 47-72.

Kirkwood, G. M. (1958) A Study in Sophoclean Drama. Ithaca: Cornell University Press.

Kitto, H. D. F. (1958) Sophocles: Dramatist and Philosopher. Oxford: Oxford University Press.

Kitto, H. D. F. (1961) Greek Tragedy. London: Methuen.

Knox, B. M. W. (1957) Oedipus at Thebes. New Haven: Yale University Press

Knox, B. M. W. (1984) 'Introduction [to Oedipus the King].' - Sophocles: The Three Theban Plays (tr. R. Fagles). London; New York: Penguin, 131-153.

Landfester, M. (1990) 'Über Sinn und Sinnlosigkeit menschlichen Leids in den Tragödien Sophokles: zum Erkenntnisfortschritt in der neueren Sophoklesforschung.' - AEA 36, 53-66.

Lawrence, S. E. (1976) 'Artemis in the Agamemnon.' - AJP 97, 97-110.

Lawrence, S. E. (1998) 'The God that is truly God and the Universe of Euripides' Heracles.' - Mnemosyne 51, 129-46.

Lawrence, S. E. (2007) 'Eteocles' Moral Awareness in Aeschylus' Seven.' - CW 100, 335-53.

Lefèvre, E. (1987) 'Die Unfähigkeit, sich zu erkennen: Unzeitgemässe Bemerkungen zu Sophokles' Oidipus Tyrannos.' - WüJbb 13, 37-58.

Lesky, A. (1965) Greek Tragedy (tr. H. A. Frankfort). London: Benn.

Lurje, M. (2004) Die Suche nach der Schuld: Sophokles' Oedipus Rex, Aristoteles' Poetik und das Tragödienverständnis der Neuzeit. München; Leipzig: Saur.

Parker, R. (1999) 'Through a Glass Darkly: Sophocles and the Divine.' - Griffin, J. (ed.), Sophocles Revisited. Oxford: Oxford University Press, 11-30. 
Peradotto, J. (1992) 'Disauthorizing Prophecy: the Ideological Mapping of Oedipus Tyrannus.' - TAPA 122, 1-15.

Rehm, R. (1992) Greek Tragic Theatre. London; New York: Routledge.

Reinhardt, K. (1979) Sophocles (tr. H. and D. Harvey). Oxford: Blackwell.

Schmitt, A. (1988) 'Menschliches Fehlen und tragisches Scheitern. Zur Handlungsmotivation im sophokleischen König Ödipus.' - RhM 131, 8-30.

Schwartz, J. D. (1986) 'Human Action and Political Action in Oedipus Tyrannus.' Euben, J. P. (ed.), Greek Tragedy and Political Theory. Berkeley; Los Angeles: University of California Press, 183-209.

Scodel, R. (1984) Sophocles. Boston: Twayne.

Seale, D. (1982) Vision and Stagecraft in Sophocles. London: Croom Helm.

Segal, C. (1981) Tragedy and Civilization: An Interpretation of Sophocles. Cambridge, MA: Harvard University Press.

Segal, C. (1995) Sophocles' Tragic World. Cambridge, MA: Harvard University Press.

Segal, C. (2001) Tragic Heroism and the Limits of Knowledge. New York; Oxford: Oxford University Press.

Versényi, L. (1974) Man's Measure: A Study of the Greek Image of Man from Homer to Sophocles. Albany, NY: State University of New York Press.

Whitman, C. H. (1951) Sophocles: A Study of Heroic Humanism. Cambridge, MA: Harvard University Press.

Winnington-Ingram, R. P. (1980) Sophocles: An Interpretation. Cambridge: Cambridge University Press. 